\title{
PENGEMBANGAN WEB SEMANTIK SILSILAH KELUARGA KAWITAN TANGKAS KORI AGUNG DENGAN METODE PENCARIAN DEPTH FIRST SEARCH
}

\author{
I Putu Tangkas Sedayatana ${ }^{1}$, I Made Agus Wirawan ${ }^{2}$, I Gede Mahendra \\ Darmawiguna $^{3}$ \\ ${ }^{123} J u r u s a n$ Pendidikan Teknik Informatika, Fakultas Teknik dan Kejuruan \\ Universitas Pendidikan Ganesha \\ Singaraja, Indonesia
}

e-mail: putu.tangkas16@gmail.com ${ }^{1}$, imade.aguswirawan@undiksha.ac.id², mahendra.darmawiguna@undiksha.ac.id ${ }^{3}$

\begin{abstract}
Abstrak
Silsilah kawitan pada dasarnya merupakan sarana bagi masyarakat Hindu untuk menghormati para leluhurnya. Namun pada kenyataanya masih ada orang yang tidak tahu atau salah dalam memilih kawitanya. Hal ini karena kurangnya informasi mengenai silsilah kawitan yang didapat oleh masyarakat. Dengan pengembangan Web Semantik Silsilah Keluarga Kawitan Tangkas Kori Agung dengan Metode Pencarian Depth First Search (DFS) dapat mengatasi masalah terkait dengan silsilah keluarga tersebut. Dengan menggunakan web masyarakat akan dapat dengan mudah mencari informasi terkait dengan silsilahnya. Web memuat data kawitan Tangkas Kori Agung dengan lengkap dari generasi ke generasi. Sehingga tidak ada lagi masyarakat yang bingung dalam menentukan kawitanya. Dalam pengembangannya, web ini dikembangan dengan menggunakan metode waterfall. Metode waterfall menggambarkan pendekatan yang sistematis dan juga berurutan pada pengembangan perangkat lunak. Mulai dari tahap perencanaan, pemodelan, implementasi, pengujian hingga pemeliharaan perangkat lunak. Pengujian dilakukan kepada kepala keluarga di kawitan Tangkas Kori Agung Tanggahan Peken. Dari hasil pengujian diperoleh hasil bahwa sistem ini mampu diterima di masyarakat dengan sangat baik.
\end{abstract}

Kata kunci: Silsilah, Web Semantik, Kawitan Tangkas, DFS

\begin{abstract}
The genealogy of the Kawitan is an essential means for Hindu society to honor its ancestors. But in fact, there are still a lot of people who do not know or wrong in choosing their Kawitan. It happens due to the lack of information about the genealogy of Kawitan gained by the community. By developing semantics web of the family tree of Kawitan Tangkas Kori Agung which used a Depth First Search (DFS) method can solve the problem which related to the family tree. By using this web, the community will be able to find information related to its genealogy easily. This web contains the data of Kawitan Tangkas Kori Agung from generation to generation. So that, there will be no people in society are confused in choosing their Kawitan. In its development, this web is developed by using waterfall method. Waterfall method describes a systematic approach and also sequentially on software development. Starting from the planning, modeling, implementation, testing, until the software maintenance. The test was conducted to the head family of Kawitan Tangkas Kori Agung Tanggahan Peken. The result of the test showed that the system is well received in the community.
\end{abstract}

Keywords : Genealogy, Semantics Web, Kawitan Tangkas, DFS

\section{PENDAHULUAN}

Bali atau yang sering disebut Pulau Dewata merupakan pulau yang terkenal dengan keindahan alam dan budaya yang menjadi daya tarik bagi para wisatawan. Budaya yang terdapat di Bali masih kental karena penduduk Bali masih memegang teguh adat dan istiadatnya. Kebudayaan 
yang berada di Bali tidak terlepas dari beberapa unsur, salah satunya adalah agama. Seperti yang kita ketahui, sebagian besar penduduk Bali menganut agama Hindu. Ajaran agama Hindu memiliki tujuan hidup yaitu bersatunya Atma dengan Brahman (Tuhan) yang disebut dengan Moksa [1]. Tujuan tersebut dapat dicapai dengan melakukan pemujaan. Pemujaan yang dimaksudkan disini adalah pemujaan kepada Tuhan Yang Maha Esa/lda Sang Hyang Widhi Wasa dengan segala manifestasinya serta pemujaan kepada para leluhur atau kawitan.

Masyarakat Hindu di Bali berasal dari kawitan yang beragam. Kata Kawitan sendiri berasal dari bahasa sansekerta yaitu Wit yang artinya asal mula. Konsep kawitan sebenarnya dibentuk dengan tujuan untuk mempererat hubungan antar keluarga. Namun masih sering ditemukan kejadian dimana seseorang tidak mengetahui kawitanya sendiri. Adapun beberapa faktor yang menyebabkan hal tersebut dapat terjadi diantaranya yaitu, yang pertama kurangnya cerita atau babad yang memuat dengan jelas terkait dengan kawitan-kawitan yang ada di Bali. Babad yang ada pun biasanya masih dalam bentuk lontar dan menggunakan Bahasa Sansekerta yang sulit dipahami oleh masyarakat umum. Faktor kedua adlah silsilah kawitan yang ada saat ini masih dalam bentuk cerita yang terdapat pada babad atau lontar tidak berupa pohon keturunan. Faktor perpindahan penduduk membuat semakin renggangnya hubungan antar keluarga, sehingga lama kelamaan membuat orang lupa kepada kawitanya. Renggangnya hubungan tersebut membuat generasi muda yang menjadi pewaris untuk meneruskan garis keturunan kawitanya pun kurang berminat dalam mempelajari sejarah silsilah dari kawitanya.

Teknologi yang telah berkembang saat ini dapat digunakan untuk mengatasi permasalahan tersebut, salah satunya dengan menyebarkan informasi melalui internet. Berbagai layanan yang terdapat pada internet membuat masyarakat dapat dengan cepat dan mudah untuk memperoleh sebuah informasi. Salah satu layanan yang paling sering digunakan adalah website atau web. Web merupakan kumpulan halaman yang menampilkan informasi data teks, data gambar, data animasi, suara, video, atau gabungan dari semuanya, baik bersifat statis maupun dinamis [2]. Sekarang ini sudah banyak web yang memuat informasi tentang kawitan-kawitan yang ada di Bali. Namun web tersebut hanya memuat informasi mengenai sejarah pejalanan dari kawitan tersebut, belum ada yang secara jelas memuat mengenai silsilah dari kawitan itu sendiri.

Untuk memudahkan masyarakat memperoleh informasi terkait dengan silsilah tersebut maka diekembangkan web semantik silsilah keluarga kawitan Tangkas Kori Agung.

\section{KAJIAN TEORI}

\section{A. Sejarah Kawitan Tangkas Kori Agung}

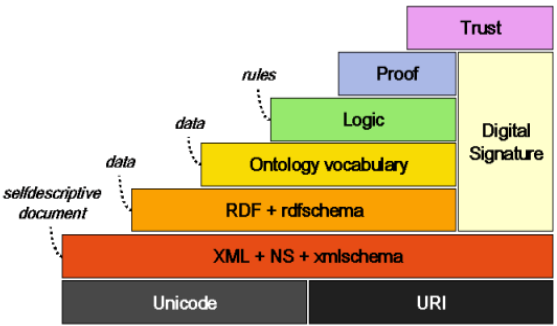

Tangkas Kori Agung memiliki sejarah panjang dalam perjalanannya. Dalam Babad Arya Kanuruhan diceritakan awal mula dari kawitan ini ialah penyerangan majapahit ke pulau Bali yang dipimpin oleh Gajah Mada Bersama dengan para Arya, termasuk Arya Kanuruhan. Arya Kanuruhan memiliki tiga orang putra yaitu Arya Brangsinga, Arya Tangkas, dan Arya Pegatepan. Arya Tangkas atau lebih dikenal dengan Pangeran Tangkas kemudian dipercaya untuk memerintah di wilayah Ketalangu. Pangeran Tangkas akhirnya menetap disana dan mempunyai seorang putra. Namun suatu hari terjadi hal yang mengejutkan dimana Pangeran Tangkas membunuh anaknya Tangkas Dimade karena Dimade telah salah mengerti isi pesan yang dikirimkan oleh Dalem (Raja Gelgel). Melihat kesedihan yang mendalam dari Pangeran Tangkas Rajapun memberikan istrinya yang sedang hamil agar keturunan dari Pangeran Tangkas tidak putus. Akhirnya lahirlah seorang putra yang diberi nama Pangeran 
Tangkas Kori Agung. Pangerang Tangkas kemudian memiliki seorang putri bernama I Gusti Ayu Tangkas Kori Agung. Agar keturunan dari Tangkas Kori Agung ini tetap ada, maka Pangeran Tangkas Kori Agung menikahkan anaknya dengan Gusti Agung Pasek Gelgel dengan status nyentana. Dari pernikahan tersebut lahirlah empat orang putra yaitu Pangeran Tangkas Kori Agung, Bendesa Tangkas Kori Agung, Pasek Tangkas Kori Agung, dan Pasek Bendesa Tangkas Kori Agung. Empat orang putra inilah yang menjadi cikal bakal tersebarnya kawitan Tangkas Kori Agung di seluruh penjuru Bali [3].

\section{B. Web Semantik (Web 3.0)}

Web Semantik atau Web 3.0 adalah generasi ketiga dari layanan internet berbasis web. Konsep Web 3.0 pertama kali diperkenalkan pada tahun 2001, saat Tim Berners-Lee, penemu World Wide Web, menulis sebuah artikel ilmiah yang menggambarkan Web 3.0 sebagai sebuah sarana bagi mesin untuk membaca halaman-halaman Web. Hal ini berarti bahwa mesin akan memiliki kemampuan membaca web sama seperti yang manusia dapat lakukan sekarang ini.

Web semantik merupakan visi masa depan web, dan informasi diberi arti eksplisit, sehingga lebih mudah diproses oleh mesin secara otomatis dan lebih mudah menyatukan informasi yang tersedia di web. Web semantik adalah perluasan dari web yang mendukung database dalam bentuk yang dapat dibaca oleh mesin [3].

Web semantik tersusun dari berbagai layer seebagai penyusun utama. Layer pendukung teknologi web semantik adalah sebagai berikut.

\section{Gambar 1 Semantic Web Layer [4]}

Gambar diatas menggambarkan
lapisan-lapisan yang mendeskripsikan
teknologi web yang dipakai untuk
membangun semantic web, dimana tiap
lapisan memiliki fungsi masing-masing.
XML, merupakan bahasa framework
yang dapat digunakan bersama bahasa
pemrograman lain seperti PHP, Java, Ruby,

dan lainnya. Digunakan untuk menyimpan serta pertukaran data pada web. XML schema, digunakan untuk mendifinisikan struktur bahasa XML tertentu.

RDF (Resource Description Framework), sebuah bahasa yang memiliki fleksibilitas dalam mendeskripsikan informasi dan metadata. RDF schema, suatu framework yang menyediakan kosakata dasar bagi RDF yang digunakan dalam aplikasi.

Ontology, merupakan kosakata yang terdiri dari komposisi dari statementstatement yang mendefinisikan suatu konsep, hubungan dan batasan dari suatu area spesifik dalam lingkup ilmu pengetahuan. Ontology dimodelkan dengan menggunakan Ontology Web Language (OWL), yang merupakan turunan dari RFDS, dimana lebih ekspresif dalam mendefinisikan relasi dan kardinalitas dari setiap class.

Logic and Proof, penalaran logis untuk membangun konsistensi dan kebenaran suatu kumpulan data dan untuk menyimpulkan kesimpulan yang tidak dinyatakan secara eksplisit. Sedangkan untuk pembuktiannya dengan menjelaskan proses dari penalaran logis tersebut.

\section{Resource Description Framework (RDF) dan RDF Schema}

Dalam arsiterktur web semantik RDF dan RDF schema merupakan layer yang berda di atas layer XML. Layer ini memungkinkan pengguna untuk membuat pernyataan tentang objek dan Uniform Resource Identifiers (URI) serta mendifinisikan kosakata yang bisa diacu dengan URI tersebut [5].

RDF Schema (RDFS) merupakan sebuah set standard sederhana dari sumber RDF yang memungkinkan untuk membuat vokabulari RDF sendiri. Model dari RDFS memiliki kemiripan dengan yang digunakan oleh object oriented, yaitu dengan memiliki class, relation, property dan instance. Class adalah kumpulan dari objek yang memiliki kesamaan karakter. Relation adalah sifat hubungan antar kelas. Property adalah karakter dari sebuah kelas. Instances adalah sebuah objek yang 
sesungguhnya. 'arti' kata menerangkan dalam RDF atau RDFS tergantung oleh beberapa faktor, termasuk peraturan sosial, bahasa natural atau penghubung ke dokumen lain. Banyak diantara arti-arti tersebut tidak dapat diakses oleh mesin.

\section{Depth First Search (DFS)}

Algoritma DFS pertama kali diperkenalkan oleh Tarjan dan Hopcroft. Mereka menunjukkan bagaimana Depth First Search (DFS) merupakan metode pencarian secara mendalam dan bagian dari blind search atau pencarian buta. Pencarian dimulai dari level paling pertama, kemudian dilanjutkan ke anak paling kiri pada level berikutnya. Demikian seterusnya sampai tidak terdapat anak lagi atau level yang paling dalam. Jika pencarian belum menemukan solusi, maka dilakukan penelusuran kembali ke node sebelumnya dan dilanjutkan ke node tetangga. Proses ini diulangi terus hingga menemukan solusi [6].

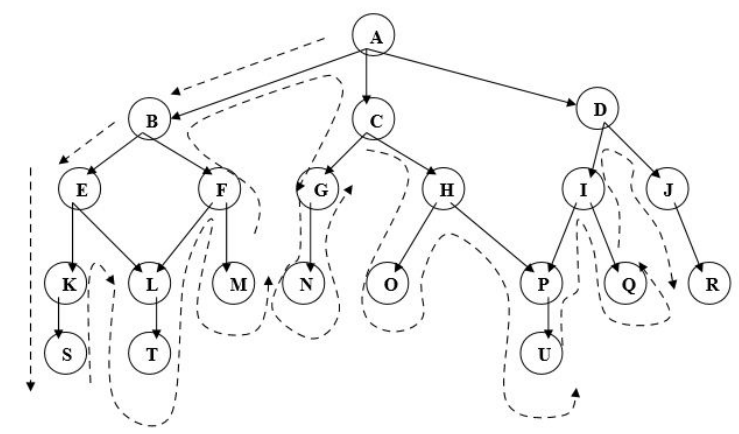

Gambar 2 Metode Depth First Search (DFS) [7]

Kelebihan dari DFS adalah :

1. Pemakaian memori hanya sedikit, karena tidak harus menyimpan semua node yang pernah dibangkitkan.

2. Jika solusi yang dicari berada pada level yang dalam dan paling kiri, maka DFS akan menemukannya secara cepat.

Kelemahan dari DFS adalah :

1. Jika pohon yang dibagkitkan mempunyai level yang dalam (tak terhingga), maka tidak ada jaminan untuk menemukan solusi.

2. Jika terdapat lebih dari satu solusi yang sama tetapi berada pada level yang berbeda, maka pada DFS tidak ada jaminan untuk menemukan solusi yang paling baik.

Pencarian rute terpendek dilakukan dengan cara membuat simpul-simpul yang menjadi titik awal, titik-titik yang akan dilalui dan juga titik akhir sebagai akhir dari tujuan atau sebagai simpul yang dicari. Dalam algoritma DFS, simpul yang telah dikunjungi disimpan dalam suatu tumpukan (stack). Antrian ini digunakan untuk mengacu simpul-simpul yang akan dikunjungi sesuai urutan tumpukan (masuk terakhir, keluar pertama) dan mempermudah proses runutbalik jika simpul sudah tidak mempunyai anak (simpul pada kedalaman maksimal).

\section{E. Laravel Framework}

Laravel framework adalah salah satu dari sekian banyak framework PHP yang tersedia. Laravel dirilis dibawah lisensi MIT. Sama seperti framework yang lain, Laravel dibangun dengan konsep MVC (ModelController-View). Laravel juga dilengkapi dengan command line tool bernama Artisan [8]. Laravel dibuat oleh Taylor Otwell sejak tahun 2012. Framework ini dikatakan clean and classy, dengan kode yang lebih singkat, mudah dimengerti, dan ekspresif [9]

Laravel dikembangkan secara khusus untuk PHP 5.3 keatas, jadi Laravel bisa memanfaatkan berbagai macam kelebihan yang dimiliki PHP versi 5.3 tersebut. Sebenarnya Laravel juga bisa digunakan pada PHP dengan versi dibawah 5.3 tetapi akan terdapat beberapa fungsi yang tidak dapat bekerja secara maksimal misalnya fungsi enkripsi password. Dengan di desain khusus untuk PHP 5.3 keatas maka Laravel bisa bisa fokus memanfaatkan fitur-fitur baru PHP 5.3 tanpa terkendala backward compatibility ..

\section{METODE}


Metode yang digunakan dalam penelitian ini adalah metode waterfall. Metode waterfall sering dinamakan siklus hidup klasik (classic life cycle), dimana hal ini menggambarkan pendekatan yang sistematis dan juga berurutan pada pengembangan perangkat lunak. Tahapan metode ini dimulai dengan spesifikasi kebutuhan pengguna lalu berlanjut melalui tahapan-tahapan perencanaan (planning), permodelan (modeling), konstruksi (construction), serta penyerahan sistem ke para pelanggan/pengguna (deployment), yang diakhiri dengan dukungan pada perangkat lunak lengkap yang dihasilkan [10].

\section{Gambar 3 Tahapan Metode Waterfall [11]}

Tahap requirement definition adalah tahap pertama yang dilakukan pengembang sistem untuk mencari dan mengumpulkan kebutuhan secara lengkap. Tahap system and software design adalah tahap selanjutnya yang dilakukan Desain sistem membantu dalam menentukan perangkat keras (hardware) dan sistem persyaratan dan juga membantu dalam mendefinisikan arsitektur sistem secara keseluruhan.Tahap implementation and unit testing adalah tahap mengimplementasikannya sistem Tahap integration and system testing adalah tahap dari sistem yang dibuat diujicobakan. Tahap operation and maintenance adalah tahap terakhir dari model waterfall. Pada tahap ini perangkat lunak yang sudah jadi, dijalankan serta dilakukan pemeliharaan.

Data yang diperoleh dalam penelitian merupakan data silsilah yang dimuat pada prasasti yang berada di pura Kawitan

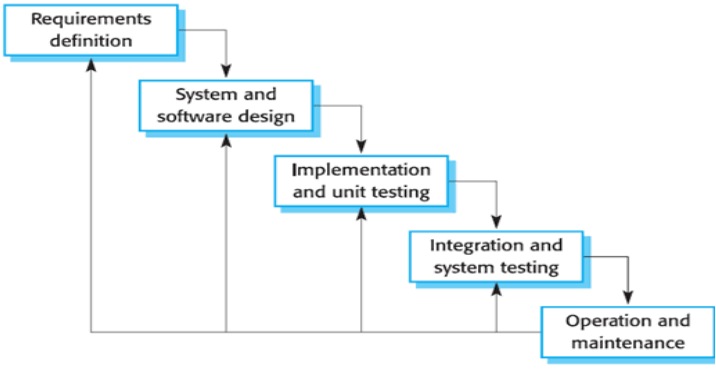

Tangkas Kori Agung di Banjar Tanggahan Peken, Desa Sulahan, Kecamatan Susut, Bangli.

Pengujian kepada pengguna digunakan untuk mengetahui tanggapan dari pengguna setelah menggunakan sistem. Uji respon pengguna akan dilakukan dengan menggunakan pengujian UEQ (User Experience Questionnaire), yang merupakan sebuah metode pengukuran UX. Metode ini menggunakan kuisioner untuk mengumpulkan feedback atau umpan balik dari pengguna ketika menggunakan sebuah produk, penggunaan kuisioner ini karena kuisioner ini dinilai lebih efektif untuk menganalisis. UEQ disusun agar dapat menghasilkan sebuah hasil penelitian atau pengujian secara efektif dan tidak memakan banyak waktu. UEQ berupa kuisioner dengan 26 pertanyaan impresi atas produk yang diberikan kepada user [12].

\section{HASIL DAN PEMBAHASAN}

\section{Hasil Penelitian}

Tahap pertama yang dilakukan adalah mencari dan mengumpulkan kebutuhan secara lengkap kemudian dianalisis dan didefinisikan yang merupakan bagian dari requirement analysis and definition (analisis kebutuhan dan definisi) pada model tersebut. Pada tahap ini penulis menggali informasi dan mengupulkan data serta menganalisis secara langsung pengetahuan yang ada pada masyarakat khususnya yang berkaitan dengan silsilah keluarga, salah satunya yaitu silsilah keluarga kawitan Tangkas Kori Agung. Berdasarkan dari hasil pengumpulan informasi yang telah dilakukan oleh penulis didapatkan silsilah keluarga kawitan Tangkas Kori Agung yang berupa prasasti di Banjar Tanggahan Peken, Desa Sulahan, Kecamatan Susut, Bangli. Prasasti tersbutlah yang menjadi sumber informasi terkait perjalanan leluhur dari generasi ke generasi dari kawitan tersebut. Dengan sedikitnya sumber terkait informasi tersebut membuat masyarakat sulit untuk mendapatkan informasi terkait silsilah tersbut. Apalagi prasasti merupakan sebuah benda yang diskralkan sehingga untuk dapat membukanya diperlukan upacara tertentu yang tidak bisa dilakukan sembarangan.

Tahap ini merupakan tahap kedua dalam model waterfall yaitu masuk kedalam bagian dari System and Software Design 
(sistem dan desain perangkat lunak). Tahap ini memaparkan tahapan awal dari perangkat lunak yang akan dikembangkan, yaitu meliputi kebutuhan perangkat lunak, tujuan pengembangan perangkat lunak, masukan dan keluaran perangkat lunak, dan model fungsional perangkat lunak. Model fungsional perangkat lunak adalah sebagai berikut.

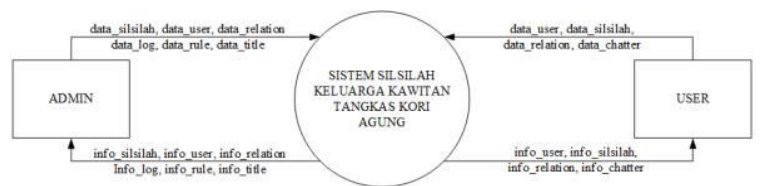

Gambar 4 Diagram Konteks

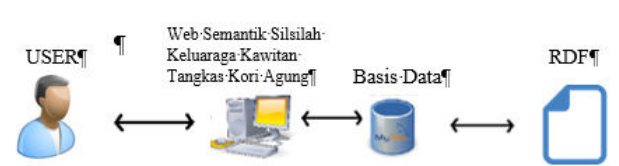

Gambar 5 Arsitektur Perangkat Lunak

User yang telah terdaftar di dalam sistem akan dapat menambahkan anggota keluarganya ke sistem. Data yang ditambahkan akan disimpan ke dalam database sistem. Database tersebut kemudian akan di ubah kedalam bentuk RDF.

Tahap Implementasi, tahapan ini, rancangan tampilan yang telah dibuat pada tahapan sebelumnya diimplementasikan menjadi sebuah perangkat lunak yang telah berfungsi dan dapat digunakan oleh pengguna sesuai dengan fungsi-fungsi yang telah ditetapkan sebelumnya. Adapun implementasi tampilan antarmuka perangkat lunak Web Semantik Silsilah Keluarga Kawitan Tangkas Kori Agung dengan Metode Pencarian Depth First Search adalah sebagai berikut.

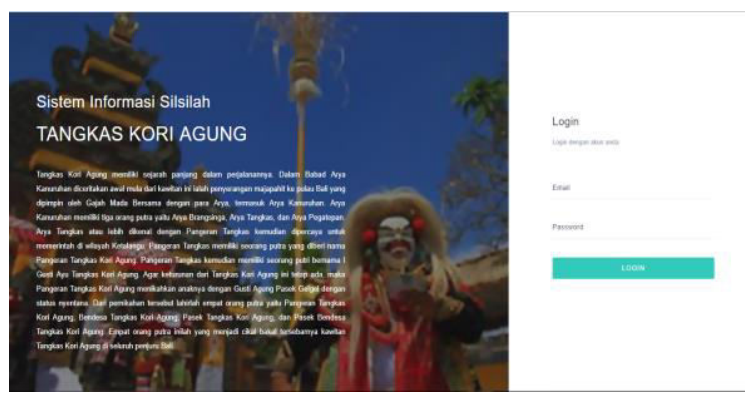

Gambar 6 Halaman Login ke Sistem

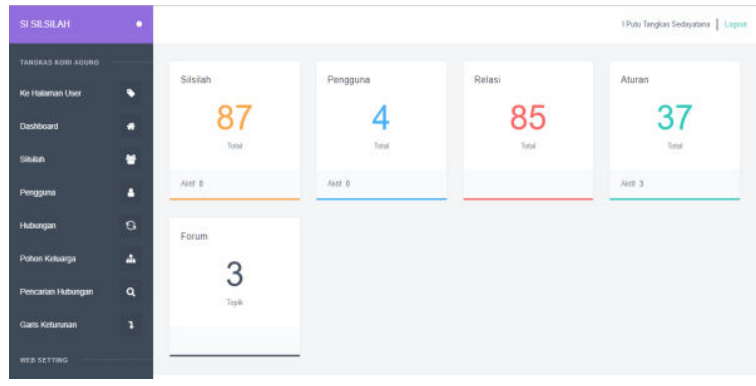

Gambar 7 Tampilan Dashboard Admin

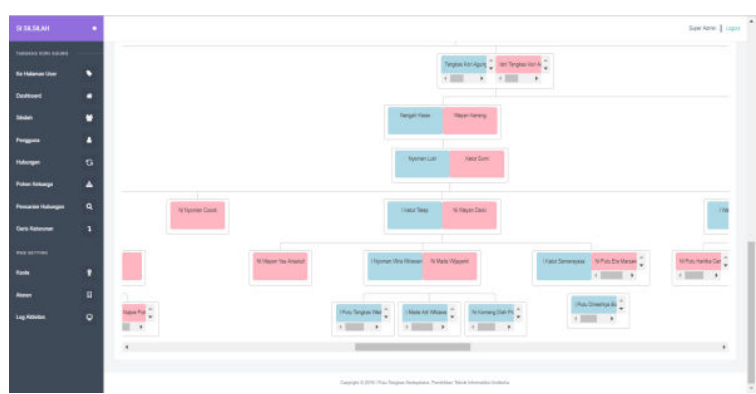

Gambar 8 Tampilah Pohon Keluarga Kawitan Tangkas Kori Agung

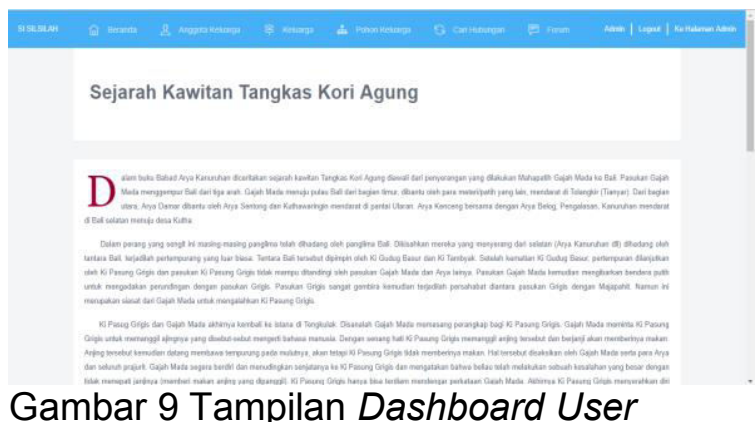

Gambar 9 Tampilan Dashboard User

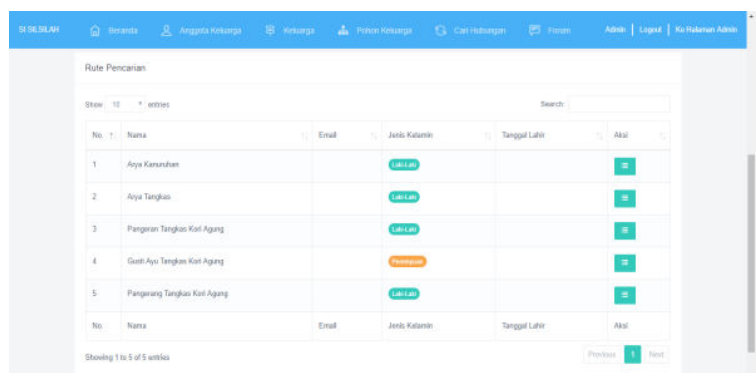

Gambar 10 Tampilan Hasil Pencarian DFS

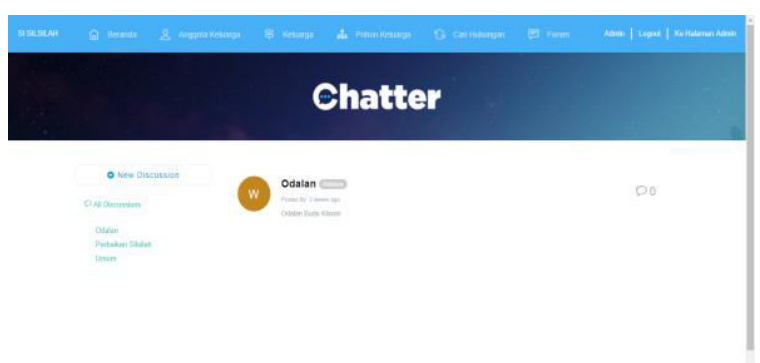

Gambar 11 Tampilan Forum Diskusi 
Tahap Pengujian, Pengujian ini dilakukan dengan melibatkan pengguna yang mana nantinya akan menggunakan sistem secara langsung. Adapun pengguna yang dilibatkan adalah populasi keluarga kawitan Tangkas Kori Agung sebanyak 10 orang. Hasil dari pengujian adalah sebagai berikut.

Tabel 1 Hasil Analisis Data dengan UEQ Data Analysis Tool

\begin{tabular}{|c|c|c|c|c|c|c|l|l|}
\hline Item & Mean & Variance & Std. Dev. & No. & Left & Right & Skale & \\
\hline 1 & 1.8 & 0.6 & 0.8 & 10 & menyusahkan & menyenangkan & Daya tarik \\
\hline 2 & 2.1 & 0.5 & 0.7 & 10 & tak dapat dipahami & dapat dipahami & Kejelasan \\
\hline 3 & 2.2 & 0.2 & 0.4 & 10 & kreatif & monoton & Kebaruan \\
\hline 4 & 2.5 & 0.5 & 0.7 & 10 & mudah dipelajari & sulit dipelajari & Kejelasan \\
\hline 5 & 2.8 & 0.2 & 0.4 & 10 & bermanfaat & kurang bermanfaat & Stimulasi \\
\hline 6 & 1.5 & 0.3 & 0.5 & 10 & membosankan & mengasyikkan & Stimulasi \\
\hline 7 & 2.1 & 0.5 & 0.7 & 10 & tidak menarik & menarik & Stimulasi \\
\hline 8 & 2.1 & 0.8 & 0.9 & 10 & tak dapat diprediksi & dapat diprediksi & Ketepatan \\
\hline 9 & 1.8 & 0.4 & 0.6 & 10 & cepat & lambat & Efisiensi \\
\hline 10 & 2.6 & 0.3 & 0.5 & 10 & berdaya cipta & konvensional & Kebaruan \\
\hline 11 & 2.4 & 0.7 & 0.8 & 10 & menghalangi & mendukung & Ketepatan \\
\hline 12 & 2.8 & 0.2 & 0.4 & 10 & baik & buruk & Daya tarik \\
\hline 13 & 0.8 & 0.4 & 0.6 & 10 & rumit & sederhana & Kejelasan \\
\hline 14 & 2.2 & 0.4 & 0.6 & 10 & tidak disukai & menggembirakan & Daya tarik \\
\hline 15 & 2.3 & 0.5 & 0.7 & 10 & lazim & terdepan & Kebaruan \\
\hline 16 & 2.7 & 0.2 & 0.5 & 10 & tidak nyaman & nyaman & Daya tarik \\
\hline 17 & 2.7 & 0.2 & 0.5 & 10 & aman & tidak aman & Ketepatan \\
\hline 18 & 2.6 & 0.3 & 0.5 & 10 & memotivasi & tidak memotivasi & Stimulasi \\
\hline 19 & 2.7 & 0.2 & 0.5 & 10 & memenuhi ekspektasi & tidak memenuhi ekspektasi & Ketepatan \\
\hline 20 & 2.2 & 0.4 & 0.6 & 10 & tidak efisien & efisien & Efisiensi \\
\hline 21 & 2.5 & 0.3 & 0.5 & 10 & jelas & membingungkan & Kejelasan \\
\hline 22 & 2.6 & 0.3 & 0.5 & 10 & tidak praktis & praktis & Efisiensi \\
\hline 23 & 2.4 & 0.3 & 0.5 & 10 & terorganisasi & berantakan & Efisiensi \\
\hline 24 & 2.3 & 0.5 & 0.7 & 10 & atraktif & tidak atraktif & Daya tarik \\
\hline 25 & 2.7 & 0.2 & 0.5 & 10 & ramah pengguna & tidak ramah pengguna & Daya tarik \\
\hline 26 & 2.8 & 0.2 & 0.4 & 10 & konservatif & inovatif & Kebaruan & \\
\hline & 0 & & & & & ana \\
\hline
\end{tabular}

Dari hasil analisis yang dilakukan dengan mengubah 26 item penilaian pada angket UEQ menjadi 6 skala yaitu daya tarik, kejelasan, efisiensi, ketepatan, stimulasi, dan kebaruan sistem web semantik silsilah keluarga kawitan Tangkas Kori Agung mencapai hasil sebagai berikut.

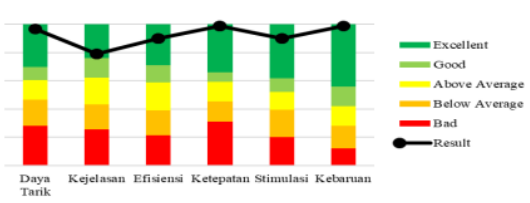

Gambar 12 Grafik Hasil Responden
Dari skala daya tarik, aplikasi ini mencapai nilai 2,417, skala kejelasan 1,975. Efisiensi mencapai nilai 2,250, ketepatan mencapai nilai 2,475 ; stimulasi mencapai nilai 2,25; dan skala yang terakhir yakni skala kebaruan yang mencapai nilai 2,475 atau dengan predikat sangat baik.

Tahap terakhir tetapi bukan yang akhir adalah mengoperasikan dan memelihara sistem yang telah dikembangkan. Tahap ini adalah bagian dimana kita melakukan kegiatan rutin seperti system maintenance, backup data dan system modification.

2. Pembahasan 
Sistem Web Semantik Silsilah Keluarga Kawitan Tangkas Kori Agung dengan Metode Pencarian Depth First Search dikembangkan dengan menggunakan model Waterfall. Model waterfall yaitu model yang bersifat sistematik dan berurutan dalam membangun perangkat lunak, dimulai dari analisis, desain, pengodean, pengujian, dan tahap pendukung (support) atau pemeliharaan. Pada tahap analisis dilakukan analisis solusi dan mencari silsilah keluarga kawitan sebagai sumber utama dalam membangun sistem ini. Pada sistem ini silsilah yang digunakan merupakan silsilah kawitan keluarga yang terdapat pada prasasti di Banjar Tanggahan Peken, Desa Sulahan, Kecamatan Susut, Kabupaten Bangli.

Setelah ditentukan kebutuhankebutuhan fungsional pada sistem, maka dilanjutkan dengan proses perancangan desain sistem, tahap ini dimulai dengan mendesain Data Flow Diagram (DFD), arsitektur perangkat lunak, Entity Relationship Diagram (ERD), antarmuka, desain struktur data, dan pembuatan RDF.

RDF merupakan pemodelan informasi yang dapat digunakan untuk berbagi informasi dengan sistem lain. Pembuatan RDF pada web semantik silsilah keluarga kawitan Tangkas Kori Agung ini menggunakan sebuah plugin yang bernama EasyRdf. Penggunaan plugin dapat mempermudah dalam mengubah database menjadi RDF. Untuk mengubah database menjadi RDF yang perlu diperhatikan yaitu menentukan vocabularies yang sesuai, dimana pada web semantik ini vocab yang digunakan adalah vocab relationship. Vocab relationship digunakan untuk mendeskripsikan hubungan antar individu sehingga cocok digunakan dalam pembuatan RDF web semantik silsilah keluarga kawitan Tangkas Kori Agung. Pada vocab relationship sudah ditentukan bagaimana cara mendeskripsikan suatu hubungan sesorang seperti contoh mendeskripsikan hubungan anak menggunakan vocab ChildOf, hubungan menikah menggunakan vocab SpouseOf begitu seterusnya dalam menentukan hubungan antar individu yang lainnya. RDF yang telah dihasilkan dapat digunakan untuk berbagi data yang terdapat pada sistem silsilah keluarga kawitan Tangkas Kori Agung dengan sistem lain yang membutuhkan. Untuk menguji hasil dari RDF tersebut, dibuatkan sebuah sistem yang berfungsi untuk menampilkan hasil RDF yang telah dibuat. Hasil dari tampilan RDF tersebut dapat dilihat pada Gambar 13.

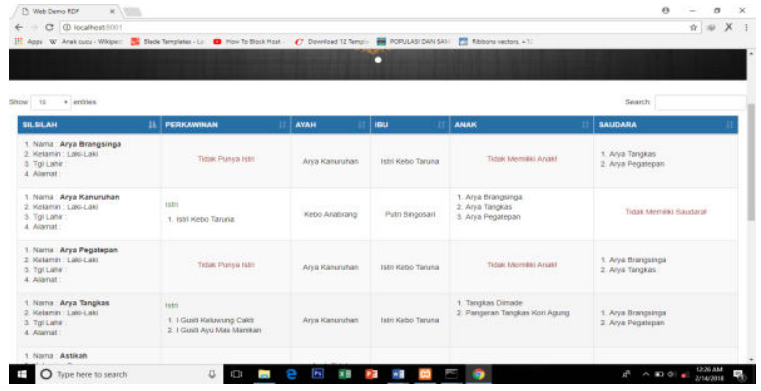

Gambar 13 Hasil Tampilan RDF pada Sistem Lain

Pada gambar diatas merupakan tampilan dari hasil RDF yang telah dibuat dari database sistem silsilah keluarga kawitan Tangkas Kori Agung. Pada tampilan tersebut RDF yang telah dibuat tersebut kemudian ditampilkan pada sistem lain yang digunakan sebagai pengujian untuk menampilkan hasil RDF tersebut. Tampilan yang dibuat pada sistem pengujian tersebut dibuat dalam bentuk tabel yang memuat data-data orang serta hubungan yang dimiliki.

Pada sistem ini juga terdapat metode pencarian Depth First Search (DFS). Pecarian ini bertujuan untuk menampilkan urutan silsilah dari seseorang ke orang lain. Urutan ini merupakan urutan dari generasi ke generasi dari orang tersebut. Hasil dari pencarian tersebut kemudian ditampilkan dalam bentuk tabel. Hasil dari pencarian menggunakan DFS tersebut dapat dilihat pada Gambar 14.
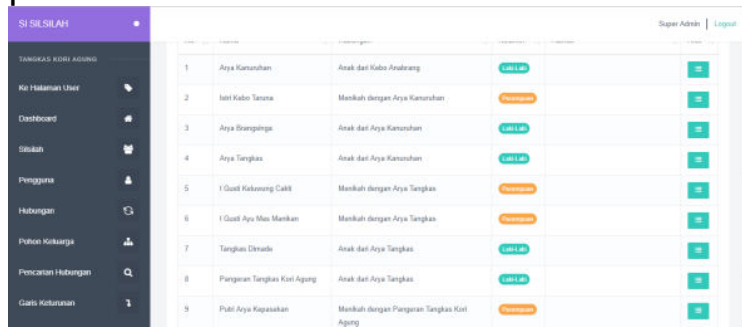

Gambar 14 Hasil Pencarian dengan Metode DFS 


\section{SIMPULAN}

Aplikasi ini memiliki beberapa fitur yang dapat membantu masyarakat dalam mengatasi permasalahan terkait dengan silsilah keluarganya, diantaranya yaitu fitur Pohon Keluarga yang menampilkan pohon keluarga keseluruhan dari kawitan, fitur Pencarian Hubungan yang dapat memperlihatkan hasil pencarian dari generasi ke generasi hubungan antar orang pada silsilah terbut, dan fitur Forum sebagai sarana berinteraksi bagi para pengguna sistem sehingga dapa menjaga eratnya hubungan antar warga pada kawitan tersebut.

Respon pengguna yaitu masyarakat yang menjadi warga dari kawitan Tangkas Kori Agung terhadap aplikasi Web Semantik Silsilah Keluarga Kawitan Tangkas Kori Agung dengan Metode Pencarian Depth First Search mendapat respon yang baik, mereka sangat tertarik dan antusias untuk mencoba sistem. Dari hasi uji di lapangan terhadap 10 masyarakat warga Kawitan Tangkas Kori Agung didapatkan hasil bahwa sistem masuk kategori sangat baik.

\section{REFERENSI}

[1] Nirwana. Nirwana dan Cara Pencapaianya dalam Agama Hindu.2015.100.

[2] Riyadi, A.S.,Retnandi, E., Deddy, A. Perancangan Sistem Informasi Berbasis Website Subsistem Guru di Sekolah Pesantren Persatuan Islam 99 Rancangbango.2012.
[3] Arnita, I.G., Catra, I.D., Maka, I.B., Sujana, I.N., Sancaya, I.D. Babad Arya Kanuruhan.1997.

[4] Koivunen, R., Eric, M. W3C Semantic Web Activity.2001.w3.org.

[5] Nurnawati,E.K. Representasi Database Berbasis Ontlogi dengan Resource Description Framework (RDF).

[6] Herwanto, A., Purnama, B.E. Penerapan Metode Depth First Search pada Pencarian Rute Bus Kota Berbasis Web mobile di Solo.2013.

[7] Hendry.Perbandingan Metode Depth First Search (DFS) dan Breadth First Search (BFS) untuk Mengidentifikasi Kerusakan Handphone.2011.

[8] Aminudin.Cara Efektif Belajar Framework Laravel. Yogyakarta:CV. Lokomedia:2015.

[9] Khasanah, A.K. Pengembangan dan Analisis Kualitas Berdasarkan ISO 9126 Aplikasi Pendeteksi gaya Belajar Model Vak (Visual, Auditorial, Kinestesik).2015

[10] Galandi, F. Metode Waterfall : Definisi, Tahapan, Kelebihan dan Kekurangan. Retrieved from pengetahuandanteknologi.com: http://www.pengetahuandanteknologi.co m/2016/09/metode-waterfall-definisitahapan.html.2014

[11] Sasmito,G.W. Penerapan Model Waterfall pada Desain Sistem Informasi Geografis Industri Kabupaten Tegal.Jurnal Informatika:Jurnal Pengembangan IT (JPIT).2017.

[12] Lestari,P.N., Santosa,P.I., Frediana,R. Pengukuran Pengalaman Pengguna dalam Menggunakan Sistem Informasi Akademik. Seminar Nasional Teknologi Informasi dan Komunikasi (SENTIKA) 2016: 136-143. 